\title{
IMPLIKASI JANJI (WA'D) DALAM TRANSAKSI SYARIAH TERHADAP TRANSAKSI IJARAH MUNTAHIYA BITTAMLIK
}

\author{
Achmad Zaky \\ achmadzaky@ub.ac.id \\ Luluk Farida \\ Universitas Brawijaya
}

\begin{abstract}
The aim of this research is to describe the implications arising from the introduction of DSN-MUI Fatwa No.85/DSN-MUI/XII/2012 about appointments ( $\left.w a^{\prime} d\right)$ in sharia financial and business transactions on Ijarah Muntahiya Bittamlik (IMBT). This study analyzes the practices of IMBT based on the guidelines which are Fatwa DSN-MUI No.27/2002 and PSAK 107, Accounting for Ijarah after aplication of DSN-MUI Fatwa No.85/DSNMUI/XII/2012. This research is a descriptive literature study. The findings indicate that the application of the DSN-MUI Fatwa No.85/DSN-MUI/XII/ 2012 is needed by transactions using Wa'd especially IMBT because it can bring benefits, as they ensure legal certainty and the continuity of contracts. However, there is another impact of the adoption of DSN-MUI Fatwa No.85/DSN-MUI/XII/ 2012, namely IMBT has a Ta'alluq risk and potentially meet the criteria of a conditional purchase. Referring to the adoption of PSAK 107, DSN-MUI Fatwa No.85/DSN-MUI/XII/2012, it also results in the risk of Capital Lease criteria fulfillment on the akad of IMBT.
\end{abstract}

Key words: fatwa DSN-MUI No.85/DSN-MUI/XII/2012, wa'd, ijarah muntahiya bittamlik, PSAK 107

\begin{abstract}
ABSTRAK
Penelitian ini bertujuan menjelaskan dampak implementasi Fatwa DSN-MUI No. 85/DSNMUI/XII/2012 tentang janji dalam transaksi keuangan dan bisnis syariah pada akad Ijarah Muntahiya Bittamlik (IMBT). Penelitian ini menganalisis implementasi akad Ijarah Muntahiya Bittamlik terhadap Fatwa DSN-MUI No. 27/2002 dan PSAK 107 tentang Akuntansi Ijarah setelah penerapan Fatwa DSNMUI No. 85/DSN-MUI/XII/ 2012 tentang janji dalam transaksi keuangan dan bisnis syariah. Metode penelitian ini adalah deskriptif dengan pendekatan studi kepustakaan. Hasil temuan pada penelitian ini menunjukkan bahwa Fatwa DSN-MUI No. 85/DSN-MUI/XII/2012 tentang janji dalam transaksi keuangan dan bisnis syariah diperlukan dalam transaksi yang menggunakan $\mathrm{Wa}^{\prime} a d$, khususnya transaksi Ijarah Muntahiya Bittamlik karena mampu mendatangkan manfaat yaitu kepastian hukum dan terjaminnya keberlangsungan akad. Namun dampak lain yang timbul dari aplikasi Fatwa DSN-MUI No.85/DSN-MUI/XII/2012 yaitu akad Ijarah Muntahiya Bittamlik berisiko Ta'alluq dan berpotensi memenuhi kriteria jual beli bersyarat. Merujuk PSAK 107 tentang Akuntansi Ijarah ternyata menunjukkan indikasi bahwa aplikasi Fatwa DSN-MUI No. 85/DSN-MUI/XII/2012 juga mengakibatkan ada risiko terpenuhinya kriteria Capital Lease pada akad Ijarah Muntahiya Bittamlik.
\end{abstract}

Kata-kata kunci: fatwa DSN-MUI No.85/DSN-MUI/XII/2012, wa'd, IMBT, PSAK 107

\section{PENDAHULUAN}

Data statistik menunjukkan pada tahun 2011 pembiayaan syariah berbasis akad Ijarah berjumlah 7.345 transaksi, namun pada tahun 2013 dan 2014 akad Ijarah mengalami pertumbuhan yang cukup tinggi dengan total transaksi 11.620 (Zaky, 2014). Data tersebut membuktikan bahwa lembaga keuangan syariah kini semakin dipercaya oleh masyarakat jika dilihat dari jumlah pembiayaan yang dilakukan mengalami kenaikan khusunya pada akad Ijarah.

Pertumbuhan transaksi ijarah sejatinya bukanlah hal yang mengejutkan, mengingat 
penduduk Indonesia mayoritas menganut agama Islam sehingga berpotensi bagi keuangan Syariah (Alamsyah, 2015). Selain itu, perkembangan perekonomian yang cukup tinggi di Indonesia mencerminkan prospek ekonomi bagi lembaga keuangan syariah, yaitu mencapai 4,9 di tahun 2015 (Ariyanti, 2015). Pertumbuhan sovereign credit rating di Indonesia mendorong minat investor berinvestasi pada sektor keuangan, termasuk keuangan syariah. Serta adanya sumber daya yang melimpah di Indonesia akan mampu dijadikan sebagai jaminan untuk melakukan transaksi termasuk pada sektor keuangan syariah. Beberapa alasan yang diuraikan di atas didukung dengan penilaian dari Global Islamic Financial Report (GIFR) pada tahun 2011 yang menyebutkan bahwa Negara Indonesia menduduki peringkat keempat yang berpotensi untuk mengembangkan industri keuangan syariah (Ariyanti, 2015).

Tingginya pembiayaan yang dilakukan dengan akad Ijarah karena akad Ijarah merupakan solusi bagi nasabah yang meng hendaki manfaat dari sebuah barang namun tidak memiliki kemampuan keuangan yang memadai (Sutardi, 2009). Namun kini akad yang hanya memiliki akad tunggal seperti akad Ijarah dalam praktinya kurang bisa menutupi kebutuhan masyarakat yang beraneka ragam (Mingka, 2013). Lebih lanjut Mingka (2013), menjelaskan bahwa pengembangan produk bank syariah kini sangatlah perlu karena tuntutan zaman dan akhirya produk multiakad menjawab kebutuhan masyarakat.

Pengembangan akad Ijarah memiliki beberapa bentuk dan salah satu bentuk akad Ijarah yang memenuhi kriteria multi akad yaitu akad IMBT. Akad IMBT merupakan akad Ijarah yang diakhiri perpindahan hak milik dari obyek sewa kepada penyewa (Ascarya, 2007). Pedoman yang digunakan dalam melaksanaan pembiayaan dengan akad IMBT adalah Fatwa DSN-MUI No.27/ 2002 tentang IMBT dan PSAK 107 terkait Ijarah. Fatwa DSN-MUI No. 27/2002 telah menjelaskan bahwa perjanjian pemindahan hak milik dilakukan ketika masa Ijarah berakhir menggunakan $W a^{\prime} d$ dengan ketentuan $W a^{\prime} d$ yang digunakan tidak boleh mengikat kedua pihak. Pernyataan serupa juga terdapat pada PSAK 107 yang menegaskan bahwa akad yang digunakan untuk pemindahan hak kepemilikan pada akad IMBT adalah $W a^{\prime} d$ yang sifatnya tidak mengikat. Praktik penggunaan $W a^{\prime} d$ pada akad IMBT dijelaskan bahwa $W a^{\prime} d$ yang disepakati dalam akad harus berdiri sendiri dan tidak diperkenankan bersatu dengan akad sewa yang disepakati (Abdullah, 2010). Padahal dalam praktik dilapangan transaksi multi akad seperti akad IMBT sangat mebutuhkan keberadaan $W a^{\prime} d$ untuk menjamin kepastian keberlangsungan akad selama masa Ijarah.

Namun jika hukum pelaksanaan akad $W a^{\prime} d$ yang terdapat pada akad IMBT tidak mengikat ternyata menimbulkan kekhawatiran pada pihak yang melaksanakan akad IMBT. Hal ini didukung dengan penelitian yang dilakukan oleh Arwan (2009) yaitu jika akad pemindahan kepemilikan bersifat tidak mengikat maka ada risiko akad IMBT tidak sesuai dengan ketentuan yang telah ditetapkan yaitu Fatwa DSN-MUI No. 27/ 2002 maupun PSAK 107 tepatnya pihak yang berakad yaitu pemilik barang merasa tidak memiliki kewajiban untuk mengalihkan hak kepemilikan obyek sewa kepada penyewa dan penyewa tidak memiliki kewajiban untuk membeli obyek sewa dari pemilik, padahal tujuan adanya akad IMBT adalah sewa yang diakhiri dengan pemindahan hak kepemilikan obyek.

Sebagaimana penggunaan akad IMBT pada produk lembaga keuangan syariah Musyarakah Mutanaqisha, proses pemindahan kepemilikan obyek sewa kepada penyewa menggunakan akad IMBT. Oleh karena itu, kejelasan mengenai hukum pelaksanaan $W a^{\prime} d$ sangat diperlukan. Pihak yang terikat ketika $W a^{\prime} d$ disepakati adalah pihak yang menyatakan janji. Oleh sebab itu, muncullah gagasan agar sifat dari $W a^{\prime} d$ yang dulunya tidak mengikat agar menjadi mengikat dan ini menjadi salah satu alasan yang mendasari terbitnya Fatwa No. 85/DSN-MUI/XII/ 2012 
pada tahun 2012 (Bello dan Hassan, 2012). Dengan terbitnya Fatwa No. 85/DSN-MUI/ XII/2012 maka akad yang menggunakaan Wa'd menjadi memiliki kepastian hukum dalam hal keberlangsungan akadnya. Oleh karena itu, dengan adanya aturan mengenai hukum pelaksanaan janji yang telah disepakati maka akad yang mencantumkan $W a^{\prime} d$ didalamnya menjadi memiliki kepastian hukum dan jaminan keberlangsungan terlaksananya akad secara sempurna.

Hak bagi seseorang menerima janji yang disepakati itu sangat dilindungi oleh hukum islam (Abdullah, 2010). Selanjutnya Abdullah (2010) juga menyebutkan bahwa penggunaan $W a^{\prime} d$ sangatlah penting terutama untuk memberikan kepastian pada akad yang akan dilakukan dimasa yang akan datang. Menurut Bello dan Hassan (2012) penggunaan $W a^{\prime} d$ sudah banyak dimanfaatkan pada produk perbankan di Negara Malaysia.

Berdasarkan penelitian terdahulu yang dipaparkan ternyata fokus pembahasan yang dilakukan adalah pada urgensi kebutuhan akad $W a^{\prime} d$. Oleh karena itu, terdapat topik kajian yang membutuhkan penelitian lebih lanjut mengenai $W a^{\prime} d$ yaitu implikasi $W a^{\prime} d$ terhadap transaksi yang menggunakan $W^{\prime} d$ mengunakan regulasi lainnya. Salah satu akad yang menggunakan $W a^{\prime} d$ antara lain akad IMBT dengan regulasi terkait aspek syariah yaitu Fatwa DSN-MUI No. 27/2002 dan aspek akuntansinya yaitu PSAK 107. Penerbitan Fatwa No. 85/DSNMUI/XII/2012 ternyata menimbulkan beberapa risiko yang perlu diwaspadai khususnya dalam pada akad IMBT. Oleh karena itu, menarik untuk dikaji lebih dalam terkait implikasi akad $W a^{\prime} d$ yang dituangkan dalam Fatwa No. 85/DSN-MUI/XII/2012 terhadap PSAK 107 khususnya dalam transaksi IMBT.

\section{TINJAUAN TEORETIS}

Fatwa No. 85/DSN-MUI/XII/2012 tentang janji $\left(W a^{\prime} d\right)$ dalam transaksi keuangan dan bisnis syariah

DSN-MUI menerbitkan fatwa No. 85/ 2012 yang membahas tentang janji dalam transaksi keuangan dan bisnis syariah. Fatwa tentang janji ini dikeluarkan pada 21 Desember 2012. Alasan yang mendasari DSN-MUI menerbitkan fatwa No. 85/DSNMUI/XII/2012, yang pertama adalah janji $\left(W a^{\prime} d\right)$ sering muncul pada transaksi keuangan dan bisnis yang bersifat tunggal, paralel dan/atau dalam transaksi yang multi akad. Dalam hal ini, akad adalah hubungan antara ijab dan qabul menggunakan cara yang dihalalkan oleh syariat dan berhubungan secara langsung (Azzam, 2010) Kedua, menurut DSN-MUI perbedaan pendapat dalam hukum melaksanakan janji.

Agama Islam mengharuskan pengikutnya untuk memenuhi janji karena berkaitan dengan pahala dan dosa yang akan didapatkan. Jika ada orang yang berjanji dan tidak bisa melaksanakan maka dia akan dapat dosa namun dirinya tidak dapat dituntut oleh pengadilan hal ini karena $W a^{\prime} d$ adalah bagian kontrak yang sifatnya sukarela dan Al-Qaraf berpandangan bahwa janji itu tidak mengikat sama sekali. Berbeda dengan pendapat dari Hanafi, Shafi'i dan Sekolah Hambali serta sebagian dari ulama Maliki yang menegaskan bahwa secara agama memang hukum janji itu mengikat (Bello dan Hassan, 2012). Alasan diatas mendorong DSN-MUI untuk menetapkan Fatwa No. 85/DSN-MUI/XII/2012 tentang janji yang terdapat pada transaksi keuangan dan bisnis syariah agar bisa dijadikan pedoman dan untuk menghilangkan ketidak pastian hukum tentang kewajiban dalam menunaikan janji yang diucapkan. Fatwa DSN-MUI No. 85/2012 menyatakan bahwa janji $\left(W a^{\prime} d\right)$ adalah pernyataan dari satu pihak untuk melaksanaakan suatu hal yang baik pada pihak lain yang hukumnya mengikat (wajib dilaksanakan) dan pihak yang diberi janji (Mau'ud) boleh memaksa pihak yang menyatakan janji (Wa'id) untuk melaksanakan janjinya. Dalam melaksanakan janjinya atau menagih janji kedua pihak diharuskan tetap mengikuti aturan agama Islam maupun ketentuan pada fatwa ini. Dalam hal pelaksanaan janji pada Fatwa No. 85/2012, DSN-MUI menekankan bahwa janji 
tertulis dalam sebuah kontrak dengan syarat yang harus dilaksanakan pada obyek serta obyek dan syarat yang dijanjikan tidak boleh bertentangan dengan syar'i. Selain itu, janji akan dilaksanakan oleh pihak yang memberi janji bila pihak yang diberi janji sudah melaksanakan syarat yang terdapat pada janji. Jika dalam perjalanan pelaksanaan janji terdapat masalah atau salah satu pihak tidak memenuhi kewajibannya maka dalam Fatwa No. 85/DSN-MUI/XII/2012 DSN-MUI memustuskan agar penyelesaiannya dilakukan melalui lembaga penyelesaian sengketa berdasarkan hukum islam setelah cara musyawarah ditempuh dan tidak ditemukan solusinya.

\section{Hybrid Contract}

$W a^{\prime} d$ yang telah dibahas apada bab sebelumnya ternyata banyak diaplikasikan pada transaksi multi akad (Mingka, 2013) hal ini karena multi akad merupakan kombinasi beberapa akad produk syariah yang telah ada. Dalam fiqih kontemporer Hybrid Contract disebut juga sebagai $A l^{-} \cup$ Uqu $A l$ Murakkabah atau dalam bahasa Indonesia adalah multi akad. Hybrid Contract adalah kesepakatan dua pihak untuk melaksanakan suatu muamalah yang menggabungkan dua akad atau lebih menjadi satu dalam sebuah transaksi sehingga hak dan kewajiban yang dihasilkan menjadi akibat hukum dari satu akad baru tersebut.

Hammad (2005) mengartikan Hybrid Contract adalah kesepakatan dua pihak untuk melaksanaakan suatu akad yang mengandung dua akad atau lebih seperti jual beli dengan sewa menyewa, hibah, wakalah, muzara'ah, sahraf (penukaran mata uang), syirkah, mudharabah dan lainnya yang berakibat hukum baru yang dihasilkan menjadi satu kesatuan yang tidak bisa dipisahkan.

Selain itu, Syekh Al-Imrani mengartikan Hybrid Contract sebagai himpunan beberapa akad kebendaan yang dikandung oleh sebuah akad baik secara gabungan atau timbal balik dan hukum yang dihasilkan menjadi hukum dari satu akad (Al-Imrani, 2006). Dan hukum baru yang dihasilkan dari
Hybrid Contract berbeda dengan hukum ketika akad tersebut berdiri sendiri menurut Al-Syatiby.

Para ulama memberikan pendapat yang berbeda terkait penggabungan dua akad dalam satu transaksi. Teori syariah yang dikembangkan selama ini di Indonesia melarang adanya penggabungan dua akad dalam satu transaksi. Hal ini juga digunakan oleh ulama kontemporer. Mereka berpendapat bahwa penggabungan dua akad dalam satu transaksi bertentangan dengan prinsip syariah yang berlaku selama ini karena terdapat dalil yang melarang penggabungan beberapa akad dalam satu transaksi.

Pendapat lain dari Za'tary (2008) menjelaskan bahwa Hybrid Contract itu tidak dilarang dalam syariah, baik akad pertukaran maupun akad tabarru' asalkan semua syarat-syarat akad dipenuhi. Al-Imrani menyebutkan bahwa Hambali, ulama Syafi'iyah, mayoritas ulama Hanafiyah, dan sebagian ulama Malikiyah berpendapat bahwa penggabungan dua akad hukumnya sah dan diperbolehkan menurut syariat islam karena hukum asal dari akad adalah boleh selama tidak ada dalil yang mengharamkan atau membatalkannya. Dengan dmikian, hukum asal dari segala muamalah di dunia adalah boleh kecuali Allah SWT dan Rasul melarangnya. Hukum dasar sesuai syara' transaksi Hybrid Contract adalah boleh asalkan setiap akad yang digunakan pada Hybrid Contract ketika berdiri sendiri hukumnya boleh (Hammad, 2005).

Penggabungan dua akad dalam satu transaksi yang dilarang adalah yang akan menimbulkan riba atau yang menyerupai riba dan ketidakpastian (gharar) mengenai akad mana yang akan dipakai, praktiknya penggabungan akad yang diharamkan yaitu jika dalam dua akad yang dilakukan terdapat obyek yang sama, pelakunya sama dan waktunya sama (Karim, 2006: 49) serta menggabungkan akad qard dengan akad yang lain.

Ketiga komponen yang dimaksudkan pada akad Ijarah Muntahiya Bittamlik me- 
miliki dua komponen yaitu obyek dan subyeknya sama, hanya waktunya saja yang berbeda sesuai ketentuan yang terdapat pada Fatwa DSN-MUI No.27/DSN-MUI/ III/2002. Akad Ijarah Muntahiya Bittamlik adalah salah satu praktik Hybrid Contract yang dibolehkan oleh DSN-MUI yang diumumkan melalui fatwa DSN No. 27/DSNMUI/III/2002. KUH Perdata pasal 1338 menyatakan bahwa beberapa pihak boleh melakukan perjanjian untuk menyusun kesepakatan selama perjanjian yang dihasilkan bukanlah sesuatu hal yang terlarang. Berarti telah terjadi kesesuaian hukum antara hukum islam dan hukum KUH Perdata sehingga kedua landasan tersebut dapat digunakan secara beriringan untuk mengatur pembentukan perjanjian terkhusus pada perbankan syariah Indonesia.

Djuwani (2008) menegaskan bahwa Ijarah Muntahiya Bittamlik bukanlah penggabungan dua akad, hanya saja akad Ijarah Muntahiya Bittamlik terdiri atas dua akad yang independen, yaitu akad sewa yang diakhir masa sewa dibentuk akad baru yaitu jual beli atau hibah. Pada akad Ijarah Muntahiya Bittamlik terdapat kombinasi antara akad Ijarah dengan akad jual beli dan akad Ijarah dengan hibah. Jual beli dan hibah yang terdapat pada akad Ijarah Muntahiya Bittamlik adalah $W a^{\prime} a d$ yang sekarang masih menjadi opsi apakah akan dipakai ataupun tidak ketika akad Ijarah berakhir.

\section{$W a^{\prime} d$}

Secara bahasa dan istilah fuqaha, $W a^{\prime} d$ adalah pernyataan seseorang kepada orang lain tentang sesuatu yang akan dikerjakan dimasa yang akan datang baik itu pekerjaan baik maupun sebaliknya (Sabiq, 1987). Mahzab maliki menjelaskan bahwa $W a^{\prime} d$ akan digunakan pada perkara-perkara tabarru'. Ditinjau dari hukum islam $W a^{\prime} d$ berarti janji. Para ulama memiliki pandangan bahwa islam memiliki beberapa pandangan yang menjelaskan tentang hukumnya janji apakah wajib dilaksanakan ketika sudah disepakati. Hal ini sesuai dengan dalil yang terdapat pada hadist riwayat Al-Bukhari dan Muslim yang memuat Sabda Nabi Mohammad SAW yaitu: "Tanda orang munafik itu 3, bila berucap berdusta, jika berjanji ingkar, dan bila dipercayai mengkhianati". Ini bisa diartikan bahwa $W a^{\prime} d$ hanya mengikat secara hukum agama sedangkan hukum perundang-undangan belum bisa menuntut kepada orang yang tidak melaksanakan $W a^{\prime} d$ yang telah diucapkannya.

Wa'd diaplikasikan pada beberapa produk lembaga keuangan syariah yaitu, Ijarah Muntahiyah Bittamlik. Murabahah dengan pesananan, Syirkah Mutanaqisha, Sukuk, Foreign Exchange, Wakalah, dan Ijarah dan seterusnya. Salah satu transaksi yang akan dianalisis lebih jauh oleh peneliti pada tulisan ini untuk menjelaskan aplikasi $W a^{\prime} d$ adalah akad IMBT. Bello dan Hassan (2012) juga menjelaskan bahwa $W a^{\prime} d$ hanya mengikat satu pihak, yaitu pihak yang berjanji. $W a^{\prime} d$ berarti pemberitahuan tentang berita baik atau berita buruk, walaupun $\mathrm{Wa}^{\prime} d$ sering digunakan untuk memberi berita baik yang akan terjadi dimasa yang akan datang. Noor dan Aripin (2010) mengungkapkan bahwa $W a^{\prime} d$ adalah:

Al-Waad is a term used currently which according to Islamic transaction means 'promise'. It is so interrelated with put option and call option but had been inserted with the element of Syara' and it is very much debated lately. Application of promise can be seen in several Islamic transaction concepts for example in sale and purchase, murabahah, Syirkah mutanaqisah, ijarah, takaful etc.

Berdasarkan pernyataan di atas pengertian $W a^{\prime} d$ adalah janji, yang dewasa ini digunakan dalam transaksi keuangan dan bisnis yang berbasis syariah baik secara langsung maupun tidak menyebutkan $\mathrm{Wa}^{\prime} d$ dalam akadnya. Beberapa lembaga keuangan yang telah mengembangkan dan menggunakan akad Wa'ad diantaranya adalah Bank Central di Malaysia, Bank Islam Malaysia Berhad, Bank Muamalat Malaysia Berhad dan Citibank dan seterusnya (Bello 
dan Hassan, 2012). Berarti kini $W a^{\prime} a d$ memiliki peran yang cukup penting, selain agar akad yang telah dijadikan produk oleh lembaga keuangan syariah berjalan sesuai aturan juga mampu mengikat pelaku ekonomi agar bisa melatih untuk memenuhi janji yang telah disampaikan dan tidak merugikan pihak lain.

\section{Ijarah Muntahiyah Bittamlik (IMBT)}

Secara bahasa Ijarah Muntahiyah Bittamlik berasal dari kata Al-ijarah yang berarti upah dan Al-tamlik yang berarti menjadikan orang lain memiliki sesuatu, sedang menurut istilah Al-tamlik memiliki arti kepemilikan atas obyek (benda atau manfaat) baik ada imbalan maupun tidak (Zaky, 2014). IMBT adalah perpaduan akad sewa dan jual beli. Dari sisi Ijarah, perbedaan IMBT terdapat pada adanya opsi untuk membeli barang diakhir periode akad. Mendasar pada sisi jual beli, perbedaan IMBT terletak pada adanya penggunaan manfaat barang terlebih dahulu menggunakan akad Ijarah sebelum akad jual beli dilaksanaakan. Hal yang membedakan antara akad Ijarah dan akad Ijarah Muntahiyah Bittamlik adalah terdapat opsi perpindahan hak milik di akhir masa sewa pada akad IMBT sedangkan Ijarah tanpa perpindahan hak milik.

Karim (2006) menjelaskan bahwa IMBT merupakan penggabungan dua akad, yaitu akad jual beli (Al-ba'i) dan akad sewamenyewa (Ijarah) yang diakhir masa sewa ada perpindahan kepemilikan melalui hibah atau jual beli. IMBT adalah akad sewamenyewa atas suatu obyek yang diakhiri perpindahan kepemilikan dari pemberi sewa kepada penyewa (Hijrianto: 2010). Ascarya (2007: 103) mengartikan IMBT adalah akad sewa-menyewa yang terdapat janji untuk menjual atau menghibahkan obyek sewa di akhir masa akad sehingga terjadi perpindahan kepemilikan obyek.

Karim (2006) juga menjelaskan terdapat perbedaan antara ijarah dengan konsep leasing yang umum dipahami. Pembedaan ini mempermudah pemahaman terhadap kedua konsep yang berkembang. Menurut Ramli (2005:63) IMBT adalah akad sewamenyewa antara pemberi sewa dan penyewa atas manfaat suatu obyek untuk memperoleh imbalan dari kegiatan sewa-menyewa yang dilakukan disertai opsi perpindahan kepemilikan pada saat yang ditentukan sesuai dengan kesepakatan diawal ketika akad dilaksanakan. Fuadi (2007) menjelaskan IMBT adalah akad yang menggabungkan kontrak sewa dengan jual beli dengan diakhiri perpindahan kepemilikan barang ditangan penyewa. Menurut standar akuntansi di Malaysia, IMBT adalah:

"Ijarah Muntahia Bittamleek is an Ijarah contract with an undertaking by the lessor to sell the Ijarah asset to the lesse and/or an undertaking by the lesse to purchase the Ijarah asset from the lessor by, or at, the end of the Ijarah period. The sale and purchase is affected by a separate ontract. 'Undertaking' is translated from the arabic word "Wa'd"".

Berdasarkan pengertian di atas memiliki arti bahwa diawal perjanjian pemberi sewa harus berjanji $\left(W a^{\prime} d\right)$ bahwa obyek yang disewakan akan beralih kepemilikan kepada penyewa dengan cara jual beli diakhir masa sewa. Menurut UU No. 21 /2008, IMBT merupakan akad penyediaan dana guna pemindahan hak guna atau manfaat barang atau jasa dengan transaksi sewa dengan opsi perpindahan kepemilikan obyek. IMBT menurut PSAK No. 107 yaitu Ijarah Muntahiyah Bittamlik adalah Ijarah yang disertai dengan $W a^{\prime} d$ yaitu aset yang disewakan akan berpindah kepemilikan pada waktu tertentu. Dewan Syariah Nasional Indonesia telah menetapkan Fatwa DSN-MUI No. 27/ DSN-MUI/III/2002 mengenai akad IMBT.

\section{PSAK 107 Terkait Akad Ijarah Muntahiyah Bittamlik (IMBT)}

Ikatan Akuntansi Indonesia mengeluarkan PSAK 107 tentang Ijarah yang menggantikan pedoman sebelumnya yaitu PSAK 59 tentang bank syariah. Dalam PSAK 107 pedoman mengenai perlakuan akuntansi akad Ijarah dan IMBT dibahas lebih men- 
detail dan terperinci dan PSAK 107 ini ditujukan bagi entitas yang melakukan transaksi Ijarah. Namun ruang lingkup PSAK 107 ini adalah segala pembiayaan selain obligasi yang menggunakan akad Ijarah (DSAS, 2016).

Tabel 1

Perbedaan Ijarah dan Leasing

\begin{tabular}{|c|c|c|c|}
\hline $\begin{array}{l}\text { No. } \\
\end{array}$ & Keterangan & Ijarah & Leasing \\
\hline & Obyek & Manfaat barang dan jasa & Manfaat barang \\
\hline 1. & $\begin{array}{l}\text { Metode } \\
\text { Pembayaran }\end{array}$ & $\begin{array}{l}\text { Tergantung atau tidak tergantung } \\
\text { pada kondisis barang dan jasa yang } \\
\text { disewakan }\end{array}$ & $\begin{array}{l}\text { Tidak tergantung pada kondisi } \\
\text { barang yang disewakan }\end{array}$ \\
\hline 2. & $\begin{array}{l}\text { Perpindahan } \\
\text { Kepemilikan }\end{array}$ & $\begin{array}{l}\text { 1. Ijarah, tidak ada perpindahan } \\
\text { kepemilikan }\end{array}$ & $\begin{array}{l}\text { 1. Sewa guna operasi, tidak } \\
\text { ada perpindahan }\end{array}$ \\
\hline & & $\begin{array}{l}\text { 2. IMBT, janji untuk menjual atau } \\
\text { menghibahkan di awal akad }\end{array}$ & $\begin{array}{l}\text { kepemilikan } \\
\text { 2. Sewa guna dengan hak opsi } \\
\text { untuk membeli atau tidak } \\
\text { membeli di akhir masa sewa }\end{array}$ \\
\hline 3. & $\begin{array}{l}\text { Metode } \\
\text { Perpindahan } \\
\text { Kepemilikan }\end{array}$ & $\begin{array}{l}\text { 1. Hibah } \\
\text { 2. Penjualan sebelum masa akad } \\
\text { berakhir }\end{array}$ & $\begin{array}{l}\text { Penjualan setelah masa sewa } \\
\text { berakhir }\end{array}$ \\
\hline & & $\begin{array}{l}\text { 3. Penjualan setelah masa akad } \\
\text { berakhir } \\
\text { 4. Penjualan secara bertahap }\end{array}$ & \\
\hline 4. & $\begin{array}{l}\text { Jenis Leasing } \\
\text { Lainnya }\end{array}$ & $\begin{array}{l}\text { 1. Lease Purchase tidak diperbolehkan } \\
\text { karena akadnya gharar, yakni } \\
\text { antara sewa dan beli } \\
\text { 2. Sale an lease back diperbolehkan }\end{array}$ & $\begin{array}{l}\text { 1. Lease purchase } \\
\text { diperbolehkan } \\
\text { 2. Sale and lease back } \\
\text { diperbolehkan }\end{array}$ \\
\hline
\end{tabular}

Sumber : Karim (2006)

PSAK 107 menjelaskan bahwa Ijarah adalah akad untuk memindahkan hak guna (manfaat) atas suatu obyek sewa dalam waktu yang ditentukan dengan imbalan pembayaran sewa tanpa adanya pemindahan kepemilikan obyek sewa tersebut (DSAS, 2016) atau secara akuntansi transaksi ini disebut Operating Lease. Sedangkan akad IMBT merupakan akad sewa antara pemilik obyek dengan penyewa disertai opsi perpindahan kepemilikan sesuai perjanjian yang disepakati. Transaksi perpindahan kepemilikan yang terdapat pada akad IMBT menggunakan $W a^{\prime} d$ yang tidak mengikat.

Harga sewa IMBT sesuai nilai wajar obyek dan disepakati oleh kedua belah pihak. Namun untuk penentuan biaya perolehan obyek sewa pada akad Ijarah, bila obyek sewa masuk pada kategori aset tetap maka mengacu pada PSAK 16 tentang Aset Tetap. Jika masuk pada kategori aset tidak berwujud maka mengacu pada PSAK 19 Tentang Aset Tidak berwujud.

PSAK 107 juga menjelaskan mengenai opsi yang dapat dipilih untuk melakukan opsi perpindahan kepemilikan pada akad IMBT yaitu: 1) Hibah, 2) Penjualan sebelum akad sewa berakhir, 3) Penjualan ketika akhir masa akad sewa, atau 4) Penjualan secara bertahap selama masa akad berlangsung. Pihak yang melakukan akad boleh memilih salah satu dari empat akad yang ditawarkan. Peran akad $w a^{\prime} d$ sangat menonjol dan bermanfaat pada saat akad IMBT ini dilakukan. Opsi yang ditawarkan menjadi lebih terkendali dan terjamin bagi kedua belah pihak jika diwujudkan dalam bentuk $w a^{\prime} d$.

\section{METODE PENELITIAN}

Penelitian ini merupakan penelitian deskriptif dengan menggunakan pendeka- 
tan studi kepustakaan (library research). Studi kepustakaan yaitu teknik untuk mengumpulkan data dengan cara mempelajari buku, literatur, catatan dan laporan yang ada hubungannya dengan masalah yang sedang diteliti (Nazir, 2011). Selanjutnya peneliti menentukan kerangka teori yang dijadikan landasan dalam penelitian ini menggunakan data yang dapat dikumpulkan yaitu yang berasal dari buku-buku yang membahas mengenai transaksi syariah, literatur-literatur terkait fatwa dewan standar, catatan terkait pedoman akuntansi, laporan-laporan dari berbagai pihak mengenai keberlangsungan akad, jurnal ilmiah yang telah maupun belum dipublikasikan tentang isu terkait yang diteliti, dan website internet yang berhubungan dengan tema yang dibahas.

Pertimbangan pemilihan jenis ini karena dalam penelitian ini peneliti akan memulai dengan menggambarkan praktik akad IMBT sebelum adanya Fatwa No.85/DSN-MUI/ XII/2012. Pendekatan penelitian yang digunakan oleh peneliti adalah studi kepustakaan. Studi kepustakaan yaitu teknik untuk mengumpulkan data dengan cara mempelajari buku, literatur, catatan dan laporan yang ada hubungannya dengan masalah yang sedang diteliti (Nazir, 2011).

Jenis data dalam penelitian ini merupakan data kualitatif, dimana data yang diperoleh peneliti berupa kalimat, kata, skema maupun gambar (Sugiono, 2005:14). Dalam penelitian ini peneliti menggunakan data sekunder. Data sekunder yang dimaksud adalah buku akuntansi syariah, Fatwa DSN MUI, jurnal ilmiah, serta website internet yang terkait dengan tema yang dibahas peneliti.

Teknik analisis data penelitian ini menggunakan pendekatan Miles dan Huberman (1992) dimana analisis data kualitatif dilakukan melalui tahapan data reduksi, analisis dan penyajian serta diakhiri dengan penarikan simpulan (Miles dan Huberman, 1992: 20).

Pada penelitian ini, peneliti berfokus pada pembahasan data yang mampu didapatkan. Selanjutnya peneliti mengambil kesimpulan dari hasil analisis yang sudah digabungkan menjadi perpaduan kalimat yang dapat dipahami secara utuh dan menyeluruh (Zeid, 2004). Tahapan penelitian yang dilakukan oleh peneliti adalah 1) penjabaran pemahaman terhadap akad IMBT dan Fatwa No. 85/DSN-MUI/XII/ 2012 dengan studi kepustakaan. 2) Penjabaran pemahaman terhadap implementasi Wa'd pada praktik akad IMBT, 3) Analisis implementasi Fatwa No.85/DSN-MUI/XII/ 2012 terhadap akad IMBT 4) Analisis kesesuaian yaitu mempertemukan konsep ideal akad IMBT terhadap Fatwa No. 27/ DSN-MUI/III/2002 dan PSAK No. 107 setelah Fatwa No.85/DSN-MUI/XII/2012. Secara ilustratif alur berfikir analisis dan pembahasan dalam penelitian ini tertera pada Gambar 1.

\section{ANALISIS DAN PEMBAHASAN}

Dampak dari tingginya permintaan pasar mendorong kebutuhan atau keragaman transaksi yang berakibat pula meningkatkan kompleksitas transaksi yang harus disediakan oleh LKS sehingga produk tunggal tidak lagi mampu memenuhi permintaan pasar dan memenuhi kebutuhan masyarakat dalam rangka melakukan transaksi keuangan (Mingka, 2013).

Dilain pihak ketentuan dalam ekonomi islam terkait segala transaksi harus senantiasa dilakukan sesuai dengan aturan yang tetera pada hukum syariah. Kompleksitas transaksi mendorong LKS untuk mengembangkan Hibryd Contract guna memenuhi kebutuhan masyarakat yang beranekaragam (Mingka, 2013). Dengan model ini, LKS mampu mengkombinasikan beberapa akad dalam satu akad. Beberapa produk lembaga keuangan syariah yang sedang dikembangkan telah mengandung beberapa akad didalamnya yang umumnya dinamakan multi akad. Bello dan Hassan (2013) memberi contoh beberapa akad pada produk LKS yang menggunakan $W a^{\prime} d$ adalah 1) Obligasi Syariah mengandung akad: Mudharabah, Ijarah atau Wakalah. Beberapa ada yang disertai akad Kafalah atau $W a^{\prime} d$ (Abdullah, 
2010) 2) Murabahah dengan pesanan, dimana pesanan ini membutuhkan kepastian berupa $w a ' d$ (Nazir dan Hasanuddin, 2004), 3) Musyarakah Mutanaqishah mengandung akad
Ijarah dan Musyarakah/ Syirkah disertai $W a^{\prime} d$, dan 4) IMBT mengandung akad Ijarah dengan Jual beli atau hibah dengan menggunakan $W a^{\prime} d$ dan seterusnya.

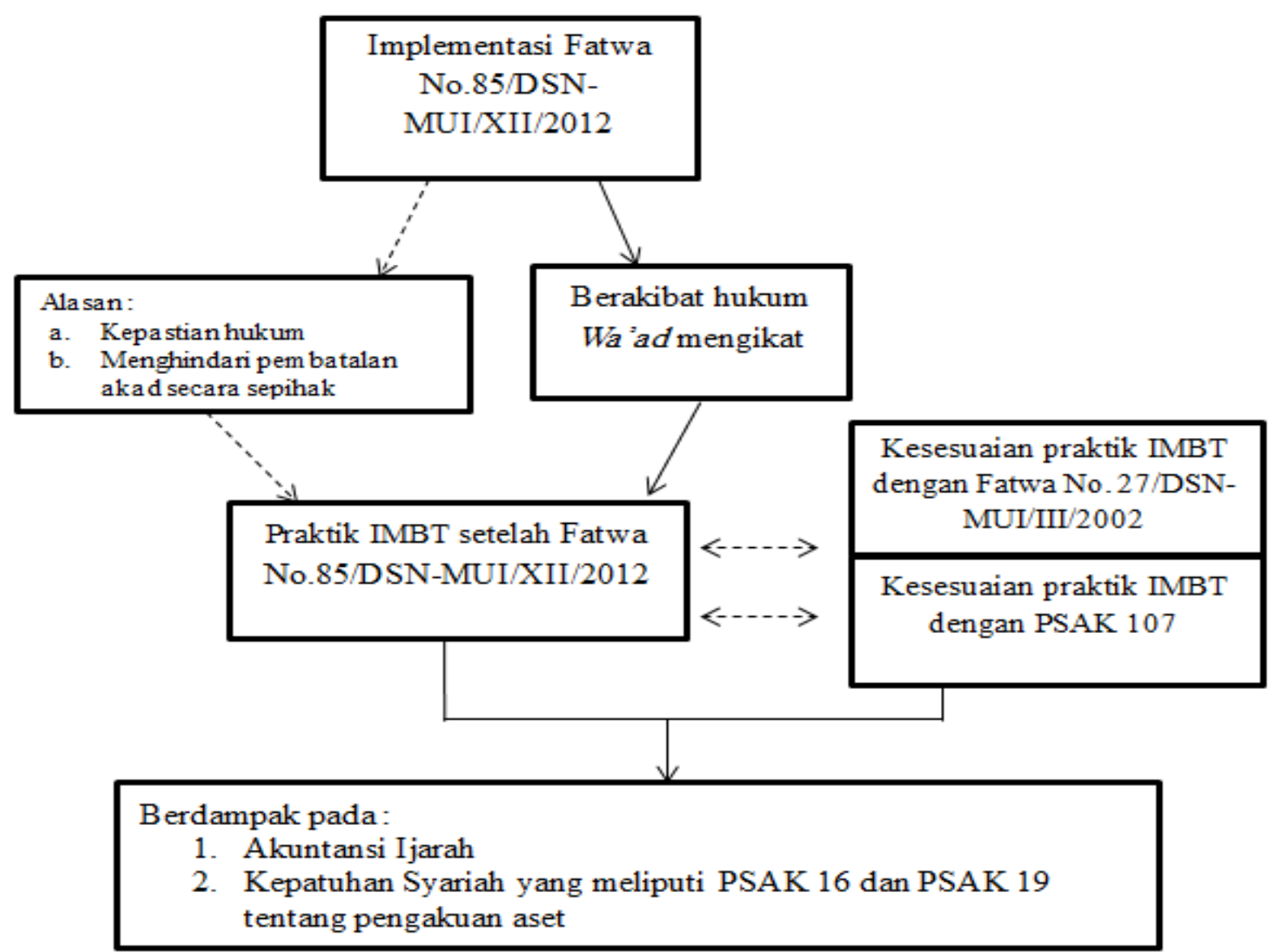

Sumber: (Olahan peneliti)

\section{Gambar 1 \\ Kerangka Analisis}

Sebagian besar dari contoh transaksi multi akad yang disebutkan diatas ternyata penggunaan akad $W a^{\prime} d$ dalam bertransaksi sangatlah mendominasi. Hal ini membuktikan bahwa dalam transaksi multi akad keberadaan $W a^{\prime} d$ sangat penting agar transaksi yang dilakukan bisa berjalan sesuai dengan ketentuan yang mengaturnya (Nazir dan Hasanuddin, 2004).

Fokus pembahasan dalam tulisan ini, peneliti menitikberatkan pada pentingnya keberadaan dan kepastian hukum wa'ad yang terdapat pada akad Ijarah Muntahiya Bittamlik. Dalam akad Ijarah Muntahiya
Bittamlik keberadaan $w a^{\prime} a d$ sangat dibutuhkan karena akan mempengaruhi keberlanjutan pelaksanaan akad perpindahan kepemilikan yang akan dilakukan ketika masa Ijarah berakhir sesuai pedoman yang terdapat pada Fatwa DSN-MUI No. 27/DSNMUI/III/2002 terkait alur pelaksanaan akad Ijarah Muntahiya Bittamlik yang sesuai dengan syariat islam. Pada sub bab selanjutnya akan dikupas lebih dalam mengenai pentingya akad wa'ad dalam transaksi Ijarah Muntahiya Bittamlik.

Mengacu pada Fatwa DSN-MUI No. 27/2002 penggunaan $W a^{\prime} d$ baik yang ter- 
dapat pada transaksi multi akad maupun yang berdiri sendiri hanya sebatas perjanjian dibawah tangan. Keberadaan $W a^{\prime} d$ bermanfaat untuk mengikat pihak yang berakad agar kedua belah pihak bisa menjalankan akad sesuai dengan peraturan yang telah ditetapkan. Namun sifat $W a^{\prime} d$ selama ini masihlah dibawah tangan hal ini karena belum ada peraturan maupun pedoman yang mengatur $W a^{\prime} d$ harus dilaksanakan. Bahkan sesuai Fatwa DSN-MUI No. 27/2002 tentang akad IMBT ada pernyataan yang menyatakan bahwa $W a^{\prime} d$ yang digunakan dalam akad akad Ijarah Muntahiya Bittamli tidak boleh mengikat pada pihak yang berakad sesuai kutipan isi Fatwa DSN-MUI No. 27/2002 yaitu:

"janji pemindahan kepemilikan yang disepakati di awal akad Ijarah adalah $W a^{\prime} d$, yang hukumnya tidak mengikat. Apabila janji itu ingin dilaksanakan maka harus ada akad pemindahan kepemilikan yang dilakukan setelah masa Ijarah selesai".

Minimnya peraturan yang mengatur tentang $W a^{\prime} d$ ternyata terdapat beberapa pihak yang berisiko mengalami kerugian akibat ketidakpastian. Dengan adanya ketidakpastian maka berpotensi terjadinya hak salah satu pihak tidak tertunaikan. Oleh karena itu, akad $W a^{\prime} d$ membutuhkan legalitas. Dalam akad IMBT keberadaan $W a^{\prime} d$ sangat dibutuhkan karena akan mempengaruhi keberlanjutan pelaksanaan akad perpindahan kepemilikan yang akan dilakukan ketika masa Ijarah berakhir sesuai pedoman yang terdapat pada Fatwa DSNMUI No. 27/2002.

\section{Kebutuhan $W a^{\prime} d$ pada Praktik Akad IMBT}

Berbagai alasan telah dikemukakan pada sub bab sebelumnya betapa perlunya $w a^{\prime} a d$ untuk dilegalkan secara hukum. Salah satu alasan yang dikemukakan adalah karena banyak dari produk lembaga keuangan syariah yang memerlukan wa'ad agar bisa dijalankan sesuai syariat islam dan tidak merugikan pihak manapun yang berakad. Fatwa DSN-MUI No. 27/2002 menyebut- kan secara khusus bahwa $W a^{\prime} d$ yang terdapat pada transaksi IMBT tidak mengikat. Hal ini dijelaskan pada bagian kedua dalam fatwa tersebut sebagai syarat pelaksanaan transaksi IMBT. Dampak Wa'd tidak mengikat ini menimbulkan penafsiran bagi pengguna akad IMBT. Pertama, ketidak terikatan itu bisa dimaknai tidak terikat untuk membuat janji pemindahan hak kepemilikan obyek IMBT diakhir periode akad Ijarah. Kedua, tidak terikat untuk melaksanakan janji yang sudah disepakati dalam akad IMBT . Penafsiran seperti ini harusnya tidak terjadi, bila hukum perjanjian yang dibuat diartikan sebagai undang-undang yang mengikat dan harus ditaati (Arwan, 2009). Adanya kekuatan hukum adalah syarat yang ditetapkan syara' agar sebuah akad memiliki kepastian untuk dilakukan.

Salah satu tujuan akad IMBT adalah pemindahan hak kepemilikan dari pemilik obyek sewa kepada penyewa saat akad Ijarah berakhir menggunakan jual beli ataupun hibah sesuai dengan kesepakatan awal akad Ijarah dilakukan. Jika opsi yang terdapat pada akad IMBT tidak mengikat maka akad IMBT kehilangan makna dan tujuannya bahkan dapat menimbulkan kezaliman.

Dengan demikian pemberi sewa akan merasa takut ketika penyewa tidak mau melakukan pembelian atau menerima hibah dari barang yang dijadikan obyek transaksi IMBT padahal barang tersebut memiliki masa ekonomis. Guna menghindari hal ini maka DSN-MUI menerbitkan fatwa No. 85/DSN-MUI/XII/2012 yang menjelaskan bahwa $W a^{\prime} d$ wajib dilaksanakan oleh pihak yang berjanji, bahkan pihak yang berjanji boleh dipaksa untuk melaksanakan janjinya.

Sesuai bunyi Fatwa No. 85/DSN-MUI/ XII/2012 pada ketentuan kedua berbunyi, “ janji $\left(W a^{\prime} d\right)$ dalam transaksi keuangan dan bisnis syariah adalah mulzim dan wajib dipenuhi (ditunaikan) oleh wa'id dengan mengikuti ketentuan-ketentuan yang terdapat dalam fatwa ini".

Dengan demikian implikasi Fatwa No. 85/DSN-MUI/XII/2012 pada akad akad IMBT memiliki beberapa manfaat maupun 
risiko. Pertama, manfaat Fatwa No. 85/DSNMUI/XII/2012 adalah adanya kepastian hukum yang bisa mewajibkan pihak yang melakukan perjanjian melaksanakan isi perjanjian yang telah disepakati. Selain itu, keberlangsungan akad juga terjamin dengan adanya pedoman hukum yang memaksa $W a^{\prime} d$ yang terdapat dalam akad bisa dijalankan sesuai tuntunan Islam tentang wajibnya melaksanakan janji. Kedua, terdapat risiko yang perlu diwaspadai terkait akad IMBT yang berpotensi terjadi pelanggaran prinsip syariah.

\section{Implikasi Fatwa DSN MUI No. 85/DSN- MUI/XII/2012 Terhadap Akad IMBT}

Fatwa DSN-MUI No. 27/DSN-MUI/ III/2002 menjelaskan bahwa segala ketentuan yang terdapat pada Fatwa No. 09/DSNMUI/IV/2000 tentang Ijarah berlaku juga pada IMBT. Hal ini dikarenakan pada IMBT terlebih dahulu akan dilakukan akad Ijarah sebelum melaksanakan akad pemindahan kepemilikan melalui jual beli atau hibah.

Rukun dan syarat Ijarah yang harus dipenuhi adalah sighat, pihak yang berakad dan obyek yang diijarahkan. Sighat adalah ijab dan qobul berupa pernyataan dari kedua belah pihak yang melaksanakan akad yaitu pihak yang memberi sewa kepada pihak yang menyewa (pihak yang berakad) baik secara lisan maupun bentuk lain. Sedangkan obyek ijarah adalah manfaat barang dan sewa atau manfaat jasa dan upah. Segala rukun dan syarat harus dipenuhi ketika pihak yang akan melakukan akad Ijarah, karena ketika Ijarah dimulai maka perjanjian Ijarah Muntahiya Bittamlik pun disepakati.

Selain rukun dan syarat yang harus diketahui oleh masyarakat ternyata dijelaskan lagi mengenai ketentuan kedua tentang obyek ijarah. Barang yang akan dijadikan obyek ijarah harus memenuhi beberapa ketentuan yang ditetapkan yakni, obyek yang di ijarahkan adalah manfaat dari barang atau jasa. Dengan kalimat tersebut sangat jelas bahwa selama masa sewa, penyewa tidak memiliki hak atas barang yang disewakan namun penyewa hanya boleh mengambil manfaat dari barang atau jasa tersebut. Selain itu, manfaat atas barang atau jasa yang dijadikan obyek ijarah harus bisa dinilai serta dapat dilaksanakan dalam kontrak dan secara hukum agama bersifat dibolehkan (tidak haram). Selanjutnya, manfaat barang yang disewakan harus dikenali secara jelas dan rinci untuk menghilangkan ketidaktahuan yang bisa mengakibatkan saling su'udzon dan berakhir pada perselisihan.

Ketentuan kedua yang terdapat pada Fatwa DSN-MUI No. 27/DSN-MUI/III/ 2002 mengenai akad Ijarah Muntahiya Bittamlik berbunyi, "Pihak yang melakukan alIjarah Al-Muntahiah bi al-Tamlik harus melaksanakan akad Ijarah terlebih dahulu. Akad pemindahan kepemilikan, baik dengan jual beli atau pemberian, hanya dapat dilakukan setelah masa Ijarah selesai". Dengan pernyataan tersebut maka telah jelas bahwa waktu pelaksanaan akan Ijarah dan jual beli atau hibah berbeda. Karena perbedaan waktu ini maka perlu adanya upaya untuk menghindari gagalnya akad perpindahan kepemilikan pada akad Ijarah Muntahiya Bittamlik. Solusinya kedua belah pihak harus melakukan kesepakatan yaitu wa'd ketika masa Ijarah dimulai yang diterangkan hukum dari $w a^{\prime} d$ itu tidak boleh mengikat sesuai dengan isi kutipan fatwa diatas mengenai praktik pelaksanaan akad Ijarah Muntahiya Bittamlik.

Pasca terbitnya Fatwa DSN-MUI No.85/ 2012 menimbulkan risiko terhadap praktik akad IMBT. Titik fokus pembahasan dalam akad IMBT yang kini menjadi syubhat adalah penggunakan $W a^{\prime} d$ pada perpindahan kepemilikan obyek sewa dari pemilik obyek kepada penyewa. Dengan pelaksanaan janji yang diwajibkan untuk dilaksanakan maka akad pemindahan kepemilikan dalam akad IMBT bisa diakui di depan saat akad Ijarah dilaksanakan.

Praktik seperti ini yang dilarang oleh agama. Fatwa DSN-MUI No. 27/DSN-MUI/ III/2002 secara khusus menyebutkan, "janji pemindahan kepemilikan, yang disepakati diawal akad Ijarah adalah $W a^{\prime} d$, yang 
hukumnya tidak mengikat. Apabila janji itu ingin dilaksanakan maka ,maka harus ada akad yang pemindahan kepemilikan yang dilakukan setelah masa Ijarah selesai". Dengan pengertian bahwa akad Ijarah berpisah secara waktu dengan akad jual beli atau hibah, maka bisa diartikan bahwa kedua akad tersebut tidak saling bergantung, hanya terdapat janji dari pemilik barang bahwa ia akan mengalihkan hak milik barang kepada penyewa ketika masa Ijarah selesai dan janji yang diucapkannya pun tidak memiliki kekuatan hukum untuk menuntutnya bila ia tidak mau melaksanakan janji itu.

Namun ketika Fatwa DSN-MUI No. 85/2012 dilaksanakan maka $W a^{\prime} d$ yang telah disepakati oleh kedua belah pihak mengikat keduanya dan berpotensi wajib ditunaikan. Inilah yang mengakibatkan akad IMBT menjadi syubhat, karena berisiko terjadi ghoror dan atau ta'alluq, yaitu terjadi ketidak pastian akad apa yang digunakan dan atau juga terjadi ketergantungan dua akad dengan pengertian bahwa akad jual beli adalah akad utama yang ingin dilakukan. Karena menghendaki pembayaran yang tidak kontan maka pihak yang melakukan kesepakatan menggunakan akad sewa sebagai syarat agar akad utama bisa terlaksana. Dengan demikian maka Fatwa DSN-MUI No. 85/ 2012 tentang janji yang mengikat menimbulkan risiko ketidaksinkronan dengan ketentuan akad IMBT pada Fatwa DSN-MUI No. 27/DSN-MUI/III/ 2002.

Jika dipandang dengan sudut pandang lain, salah satunya aspek perjanjian bersyarat dalam jual beli, implementasi Fatwa DSN-MUI No. 85/2012 dikhawatirkan menimbulkan risiko terjadi penjualan bersyarat yang tidak sesuai dengan ketentuan syar'i. Meskipun dalam hal ini masih terdapat perbedaan pandangan fiqih terhadap jual beli bersyarat. Dalam Al-Muslih (2004) kalangan Malikiyah mengatakan bahwa jual beli bersyarat yang dilarang agama yaitu ketika syarat yang diajukan bertentangan dengan akad jual beli, seperti syarat larangan menjual lagi obyeknya atau larangan meng- gunakannya. Dalam Al-Muslih (2004), ulama Hambali menyatakan bahwa jual beli bersyarat yang dilarang adalah jual beli yang syaratnya bertentangan dengan akad dan bertentangan dengan syar'i. Seperti memberi syarat bentuk usaha lain, misalkan jual beli lain atau peminjaman. Seperti penjelasan dari ulama Hambali, ketika Fatwa DSN-MUI No. 85/2012 diterapkan maka pada akad IMBT juga memiliki syarat jual beli lain yaitu akad perpindahan hak milik obyek sewa ketika masa akad Ijarah selesai.

Fatwa DSN-MUI No. 85/2012 menurut peneliti memiliki dampak yaitu unsur waktu pun juga berisiko terjadi bersamaan antara akad sewa dan pemindahan kepemilikan pada akad IMBT.

Secara ringkas kesesuaian praktik akad IMBT Setelah Fatwa DSN-MUI No. 85/2012 diterapkan akan dijelaskan pada Tabel 2.

\section{Praktik Akad IMBT Berdasarkan PSAK No. 107}

PSAK No. 107 adalah salah satu panduan yang mengatur tentang akad Ijarah sekaligus berlaku untuk akad IMBT di Indonesia selain Fatwa DSN-MUI No. 27/DSN-MUI/ III/2002. Dalam konteks perbankan islam Ijarah berarti lease contract yang mana lembaga keuangan menyewakan peralatan, bangunan atau barang lainnya kepada nasabahnya berdasarkan pembebanan biaya yang telah disepakati sebelumnya (Sjahdaini, 2005). Dalam akuntansi dikenal dengan nama leasing atau sewa guna usaha.

Ketika akad IMBT disepakati maka kepemilikan obyek sewa masih menjadi tanggungjawab pemilik barang hingga akad Ijarah berakhir dan dilakukan akad pemindahan kepemilikan kepada penyewa. Berarti hingga saat itu tanggungjawab pemeliharaan obyek sewa adalah tanggungjawab pemilik sesuai aturan dalam PSAK 107. Tetapi jika dalam akad Ijarah disepakati perjanjian khusus yang tentang perawatan obyek barang dibebankan pada pihak penyewa atau yang menyewakan tetap akan sah. Namun Nurhayati dan Wasilah (2013) menjelaskan bahwa dalam kontrak yang di- 
sepakati dilarang tercantum syarat akad yang mengharuskan penyewa menanggung biaya perawatan karena akan menimbulkan unsur ketidakpastian, kecuali jika biaya yang ditanggungkan kepada penyewa adalah biaya rutin dan immaterial itu diperbolehkan.

\section{Tabel 2}

Implikasi Fatwa No.85/DSN-MUI/XII/2012 Pada Transaksi IMBT Terhadap Fatwa DSN-MUI No. 27/DSN-MUI/III/2002

\begin{tabular}{|c|c|c|c|}
\hline No. & Fatwa & Kesesuaian & Keterangan \\
\hline \multicolumn{4}{|c|}{ Ketentuan Umum } \\
\hline \multirow[t]{4}{*}{1.} & Kesesuaian tentang Rukun dan Syarat & Akad Ijarah & \\
\hline & $\begin{array}{l}\text { Shighat Ijarah, yaitu ijab dan qobul } \\
\text { berupa pernyataan dari kedua belah } \\
\text { pihak yang berakad, baik secara } \\
\text { verbal atau bentuk lain }\end{array}$ & Sesuai & - \\
\hline & $\begin{array}{l}\text { Pihak-pihak yang berakad terdiri } \\
\text { atas: a. pemberi sewa atau jasa b. } \\
\text { penyewa atau pengguna jasa }\end{array}$ & Sesuai & - \\
\hline & $\begin{array}{l}\text { Obyek akad Ijarah: } \\
\text { a. manfaat barang } \\
\text { b.jasa atau manfaat jasa dan upah }\end{array}$ & Sesuai & - \\
\hline 2. & $\begin{array}{l}\text { Perjanjian berakad IMBT disepakati } \\
\text { ketika akad Ijarah ditandatangani }\end{array}$ & Sesuai & - \\
\hline 3. & $\begin{array}{l}\text { Hak dan kewajiban setiap pihak } \\
\text { harus dijelaskan dalam akad }\end{array}$ & Sesuai & \\
\hline \multicolumn{4}{|c|}{ Ketentuan tentang IMBT } \\
\hline 1. & $\begin{array}{l}\text { Pihak yang melaksanakan akad } \\
\text { IMBT harus melaksanakan akad } \\
\text { Ijarah dahulu. Akad pemindahan hak } \\
\text { milik melalui hibah atau jual beli } \\
\text { hanya dapat dilakukan setelah masa } \\
\text { Ijarah selesai }\end{array}$ & $\begin{array}{l}\text { Tidak } \\
\text { sesuai }\end{array}$ & $\begin{array}{l}\text { Tertulisnya janji pemindahan ke- } \\
\text { pemilikan obyek di awal kesepakan } \\
\text { dan sifatnya mengikat, maka secara } \\
\text { substansi perpindahan kepemilikan } \\
\text { dapat berpotensi terjadi diawal akad. }\end{array}$ \\
\hline 2. & $\begin{array}{l}\text { Janji perpindahan hak kepemilikan } \\
\text { yang disepakati di awal akad Ijarah } \\
\text { adalah } W a^{\prime} d \text {, yang hukumnya tidak } \\
\text { mengikat. } \\
\text { Bila janji tersebut akan dilaksanakan } \\
\text { maka harus menggunakan akad baru } \\
\text { setelah masa akad Ijarah selesai }\end{array}$ & $\begin{array}{l}\text { Tidak } \\
\text { sesuai }\end{array}$ & $\begin{array}{l}\text { Dengan fatwa No. 85, janji yang } \\
\text { terdapat pada akad IMBT menjadi } \\
\text { mengikat kepada penyewa atau } \\
\text { pemilik obyek untuk melakukan } \\
\text { pemindahan hak milik obyek Ijarah }\end{array}$ \\
\hline \multicolumn{4}{|c|}{ Ketentuan tentang lain-lain } \\
\hline 1. & $\begin{array}{l}\text { Jika salah satu pihak lalai me- } \\
\text { nunaikan kewajiban atau terjadi } \\
\text { perselisihan, maka penyelesaian di- } \\
\text { laksanakan melalui badan Arbitrasi } \\
\text { Syariah setelah tidak tercapainya } \\
\text { kesepakatan dengan musyawarah }\end{array}$ & Sesuai & - \\
\hline 2. & $\begin{array}{l}\text { Menanggung biaya pemeliharaan } \\
\text { barang }\end{array}$ & Sesuai & - \\
\hline 3. & $\begin{array}{l}\text { Menjamin bila terdapat cacat pada } \\
\text { barang yang disewakan }\end{array}$ & Sesuai & - \\
\hline
\end{tabular}


Selain peraturan yang disepakati penyewa tetap memiliki tanggungjawab untuk menjaga keutuhan obyek sewa dan membayar sewa kepada pemilik obyek. Ketentuan tentang pemanfaatan dan pemeliharaan obyek sewa yang disewakan: 1). Pemeliharaan obyek sewa. Secara prinsip dalam sebuah kontrak IMBT harus menyatakan pihak penanggung biaya pemeliharaan. Jika biaya pemeliharaan dimaksukkan dalam akad maka penyewa memiliki hak untuk mendapatkan uang ganti pemeliharaan tersebut. Hal ini berlaku jika pemilik barang menyetujuinya. Jika hanya pemikiran dari penyewa tanpa ada perjanjian sebelumnya atau bahkan tanpa sepengetahuan pemilik barang maka biaya pemeliharaan tersebuat akan dianggap sebagai hibah dan pemilik barang tidak wajib menggantinya (Hijrianto, 2010), 2). Tanggungjawab kerusakaan atau kerugi- an pada obyek sewa. Jika penyewa hanya melakukan sewa-menyewa atas manfaat obyek sewa maka ulama sepakat bahwa amanah untuk menjaga obyek sewa menjadi tanggungjawab penyewa. Namun jika obyek yang diperjanjikan mengalami kerusakaan yang mana tidak disebabkan kelalaian penyewa maka yang bersangkutan tidak dapat disalahkan kecuali jika kerusakan obyek sewa terjadi karena kelalaian penyewa maka yang bersangkutan wajib menanggungnya. Sebenarnya penyewa hanyalah mendapat izin untuk mengambil manfaat dari obyek tersebut bukan penjamin dari obyek yang diperjanjikan. Dengan demikian status kepemilikan aset pada akad IMBT menjadi tanggung jawab pemilik selama masa akad sewa belum berakhir. Ketika akad perpindahan kepemilikan dilakukan maka tanggung jawab berpindah kepada penyewa.

Tabel 3

Pengakuan dan Pengukuran Akuntansi Menurut PSAK 107 tentang Akuntansi Ijarah

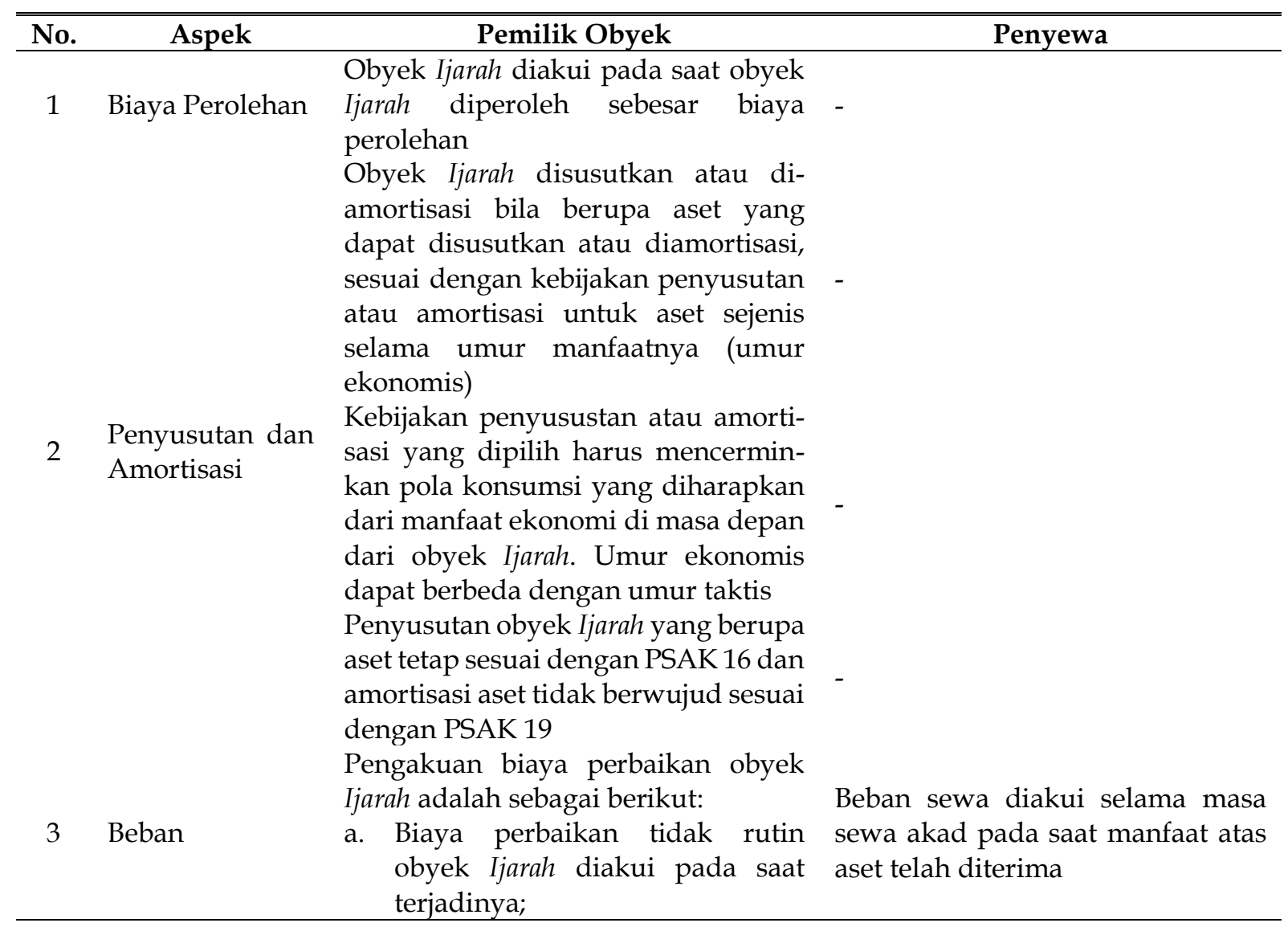




\begin{tabular}{|c|c|c|c|}
\hline No. & Aspek & Pemilik Obyek & Penyewa \\
\hline & & $\begin{array}{l}\text { b. Jika penyewa melakukan per- } \\
\text { baikan rutin obyek Ijarah dengan } \\
\text { persetujuan pemilik, maka biaya } \\
\text { tersebut dibebankan kepada } \\
\text { pemilik dan diakui beban pada } \\
\text { saat terjadinya }\end{array}$ & \\
\hline & & $\begin{array}{l}\text { Dalam IMBT melalui penjualan } \\
\text { secara bertahap, biaya perbaikan } \\
\text { obyek Ijarah ditanggung pemilik } \\
\text { maupun penyewa sebanding dengan } \\
\text { bagian kepemilikan masing-masing } \\
\text { atas obyek Ijarah. }\end{array}$ & $\begin{array}{l}\text { Biaya pemeliharaan obyek Ijarah } \\
\text { yang disepakati dalam akad men- } \\
\text { jadi tanggungan penyewa dan } \\
\text { diakui sebagai beban pada saat } \\
\text { terjadinya }\end{array}$ \\
\hline & & $\begin{array}{l}\text { Biaya perbaikan obyek Ijarah me- } \\
\text { rupakan tanggungan pemilik. Per- } \\
\text { baikan tersebut dapat dilakukan oleh } \\
\text { pemilik secara langsung atau di- } \\
\text { lakukan oleh penyewa atas per- } \\
\text { setujuan pemilik }\end{array}$ & $\begin{array}{l}\text { Biaya pemeliharaan obyek Ijarah } \\
\text { dalam IMBT melalui penjualan } \\
\text { obyek Ijarah secara bertahap akan } \\
\text { meningkat sejalan dengan pening- } \\
\text { katan kepemilikan obyek Ijarah }\end{array}$ \\
\hline
\end{tabular}

Sumber : Olahan Peneliti (2017))

\section{Risiko Kepatuhan Syariah Akad IMBT Implikasi dari Fatwa DSN MUI No. 85/DSN-MUI/XII/2012}

Sebelum Fatwa DSN-MUI No. 85/2012 terbit akad perpindahan kepemilikan yang dilakukan saat masa sewa berakhir tidak memiliki jaminan apakah bisa berjalan sesuai yang diharapkan. Namun setelah Fatwa DSN-MUI No. 85/2012 muncul maka subtansi akad perpindahan kepemilikan bisa dipastikan akan dikerjakan oleh pihak yang berakad sehingga memiliki risiko Ta'alluq.

Sejalan dengan adanya kepastian hukum yang timbul setelah penerbitan Fatwa DSN-MUI No. 85/2012 pada akad IMBT ternyata memiliki beberapa risiko terhadap kepatuhan aturan secara syariah. Dalam perjanjian akad $I M B T, W a^{\prime} d$ yang disepakati mengharuskan kedua belah pihak untuk melakukan kegiatan perpindahan kepemilikan ketika masa akad Ijarah selesai.

Secara subtansi hal ini berisiko pelaku akad akan melakukan perpindahan kepemilikan ketika perjanjian akad Ijarah dilakukan. Hal ini menyebabkan praktik akad IMBT menjadi tidak sesuai lagi dengan peraturan syariahnya yaitu Fatwa DSN-MUI No. 27/DSN-MUI/III/2002 yaitu ketika pelaku akad IMBT melakukan akad perpinda- han kepemilikan saat akad Ijarah disepakati atau secara subtantif maka hal ini akan berisiko memenuhi syarat sebuah transaksi dikatakan $T a^{\prime}$ alluq, yaitu pelaku, obyek, dan waktunya sama dalam kedua akad tersebut yaitu akad sewa-menyewa dan perpindahan kepemilikan (Karim, 2006).

\section{Risiko Implementasi PSAK 107 tentang Akad IMBT Terhadap Fatwa DSN MUI No. 85/DSN-MUI/XII/2012}

Dengan diterapkannya Fatwa DSN-MUI No. 85/2012 ternyata praktik akad IMBT memiliki risiko tidak lagi sesuai dengan PSAK 107 tentang akuntansi ijarah. Dalam PSAK tersebut jelas bahwa opsi perpindahan kepemilikan pada akad IMBT hanya akan dilakukan saat akhir masa sewa, namun dengan berlakunya Fatwa DSN-MUI No. 85/2012 memiliki risiko ketidaksesuaian karena dengan Fatwa DSN-MUI No. 85/ 2012 maka status dari akad yang dilaksanakan menjadi mengikat, dimana opsi perpindahan kepemilikan obyek sewa harus dilaksanakan. Hal ini bertentangan dengan Fatwa DSN-MUI No. 27/DSN-MUI/III/ 2002 yang melarang adanya opsi perpindahan kepemilikan hukumnya mengikat.

Selain itu dengan diberlakukannya Fatwa DSN-MUI No. 85/2012 membuat 
akad IMBT memiliki risiko sama dengan transaksi Capital Lease (Finance Lease) yang memiliki sifat berbeda dengan ketentuan dalam syariat islam. PSAK No 30 menyatakan bahwa Capital Lease merupakan sewa yang secara subtansial mengalihkan seluruh risiko dan manfaat yang terkait dengan kepemilikan obyek sewa. Padahal menurut Smith dan Skousen (1984) sebuah transaksi sewa-menyewa termasuk Capital Lease jika memiliki satu atau lebih dari sifat dari Capital Lease yaitu:

1). Ketika selesai masa sewa terjadi perpindahan hak milik kepada penyewa, 2). Dalam perjanjian yang disepakati tercantum bahwa penyewa memiliki hak untuk membeli obyek sewa dengan harga yang menguntungkan, yaitu dengan harga lebih rendah dari taksiran fair valuenya ketika hak membeli direalisasi (Opsi Bargain Purchase), 3). Masa sewa lebih dari 75\% dari umur ekonomis obyek sewa, dan 4). present value dari pembayaran sewa harus lebih dari atau sama dengan 90\% daripada harga pasar obyek sewa.

Dengan demikian jika $W a^{\prime} d$ opsi pemindahan kepemilikan pada akad IMBT yang dituangkan dalam kontrak (akad) secara otomatis dihukumi mengikat sebagaimana kandungan isi Fatwa DSN-MUI No. 85/2012, maka hampir dapat dipastikan ketika masa sewa berakhir obyek sewa berpindah menjadi milik penyewa. Hal ini menjadikan akad tersebut memenuhi unsur transaksi Capital Lease, dimana ketika masa sewa berakhir obyek sewa menjadi milik penyewa. Dengan demikian, jika pelaksanaan akad IMBT dengan menerapkan Fatwa DSN-MUI No. 85/2012 dalam kontrak, berrisiko tergolong pada transaksi Capital Lease. Konsekuensinya, penyewa seharusnya mencantumkan obyek sewa yang diperjanjikan dalam aktivanya dan pada sisi kredit mencantumkan sebagai utang.

Praktik akad IMBT yang memenuhi kriteria sifat Capital Lease dengan model $\mathrm{Wa}^{\prime} \mathrm{d}$ yang mengikat dan jika secara subtansi yang melakukan akad perpindahan kepemilikan adalah pihak yang sama maka syarat pertama Capital Lease terkait perpindahan hak milik telah terpenuhi. Syarat kedua sebuah akad digolongkan Capital Lease adalah adanya opsi membeli telah terpenuhi. Secara otomatis pada akad IMBT memang terdapat opsi untuk membeli obyek sewa di akhir masa sewa sesuai dengan PSAK 107 maupun Fatwa DSN-MUI No. 27/DSNMUI/III/2002. Syarat ketiga yaitu masa sewa akad IMBT memiliki potensi berumur lebih dari $75 \%$ jika obyek sewa akad IMBT adalah aset jangka panjang seperti rumah. Syarat keempat, transaksi dapat digolongkan Capital Lease jika present value harga sewa sama atau lebih besar dari $90 \%$ harga obyek sewa.

Zaky (2014) menjelaskan bahwa dalam akad IMBT, nilai obyek sewa merupakan jumlah dari harga pokok obyek, beban pemeliharaan, dan keuntungan yang ingin diraih. Dimana harga pokok obyek terbentuk dari nilai depresiasi (penyusutan) yang mana nilai penyusutan dalam akad IMBT yang menggunakan dasar umur akad. Sehingga ketika akad perpindahan kepemilikan dilakukan nilai obyek sewa sudah nol atau semisal nilai residu obyek. Secara umum present value obyek sewa saat akad ijarah disepakati harga sewa yang disepakati bisa sama atau bahkan melebihi $90 \%$ presen value obyek sewa.

Jika demikian yang terjadi maka secara subtantif akad IMBT telah memenuhi empat kriteria sifat transaksi Capital Lease, sehingga ada beberapa perlakuan akuntansi pada akad IMBT yang harus diganti. Jika sebelumnya ada beberapa tanggungan merupakan tanggungjawab pemilik obyek sewa kini menjadi tanggungan penyewa. Pertama, mengenai biaya perawatan selama masa sewa. PSAK 107 menjelaskan biaya perawatan dibebankan pada pemilik sewa. Namun terbitnya Fatwa DSN-MUI No. 85/2012 maka berisiko biaya perawatan menjadi tanggungan penyewa sesuai dengan apa yang tertuang pada PSAK 30 mengenai tanggungjawab penyewa dan pemilik pada transaksi Capital Lease. 
Kedua, terkait dengan biaya penyusutan obyek sewa akad IMBT. Dengan berlakunya Fatwa DSN-MUI No. 85/2012 maka terjadi potensi akad pemindahan kepemilikan dilakukan awal masa sewa, sehingga persyaratan yang pada Capital Lease tentang pembebanan segala biaya yang berkaitan dengan obyek sewa kepada penyewa juga terjadi pada akad IMBT.

Ketiga, mengenai jurnal yang diposting juga akan mengalami pergeseran. Perpindahan kewajiban posting jurnal transaksi yang terjadi setelah Fatwa DSN-MUI No. 85/2012 akan dijelaskan pada Tabel 4.

\section{Tabel 4}

\section{Perbedaan Praktik akad IMBT setelah Fatwa DSN-MUI No.85/2012}

\section{No. Sebelum Fatwa DSN-MUI No.85/2012}

1. Sesuai pedoman PSAK 107 obyek sewa merupakan tanggungjawab pemilik selama masa sewa belum berakhir.

2. Jurnal Pengakuan Beban Pemeli- haraan:
a. Pemberi sewa:
Beban Pemeliharaan
b. Penyewa:
Piutang
Kas/Utang/Perlengkapan
Kas/Utang/Perlengkapan

3. Jurnal Pengakuan Beban Penyusutan:
a. Pemberi sewa:
Biaya Penyusutan
Akumulasi Penyusutan
b. Penyewa:
Tidak ada jurnal

4. Penyajian dalam Laporan Keuangan:

a. Obyek sewa akan muncul dalam neraca pemberi sewa sebagai Aset Ijarah.

b. Munculnya Akumulasi Penyusutan pada sisi kredit neraca pemberi sewa

\section{Setelah Fatwa DSN-MUI No.85/2012} Diterbitkan

Tanggungjawab obyek sewa berpindah kepada penyewa karena secara subtansi ada risiko perpindahan kepemilikan dilakukan diawal masa sewa.

Sehubungan dengan potensi perpindahan kepemilikan yang dilakukan diawal masa akad maka subtansi tanggungjawab pemeliharaaan obyek juga berpindah kepada penyewa sehingga jurnal pengakuan beban pemeliharaan dapat berupa:

a. Pemberi sewa: Tidak ada jurnal

b. Penyewa: Beban Pemeliharaan

Kas/Utang/Perlengkapan

Berlakunya dampak secara subtansi pada beban pemeliharaan juga berdampak sama pada pengakuan beban penyusutan obyek sewa sehingga jurnal pengakuan beban penyusutan dapat berupa:

a. Pemberi sewa:

Tidak ada jurnal

b. Penyewa:

Biaya Penyusutan

Akumulasi Penyusutan

Penyajian dalam Laporan Keuangan:

Karena ada risiko perpindahan kepemilikan diawal masa akad sehingga:

a. Neraca Pemberi Sewa: Aset Ijarah telah dipindah tangankan sehingga tidak muncul lagi dalam neraca

b. Neraca Penyewa: karena telah berpindah tangan kepada penyewa sehingga muncul Aset Non-kas pada sisi debet neraca penyewa, dan pada sisi kredit muncul akumulasi penyusutan obyek sewa. 
Dilain pihak Fatwa DSN-MUI No. 85/2012 membawa beberapa hal yang berubah baik secara subtantif maupun praktiknya. Secara subtansi dengan adanya Fatwa DSN-MUI No. 85/2012 ada potensi opsi perpindahan kepemilikan obyek sewa bersifat mengikat sehingga menjadikan akad IMBT memenuhi kriteria transaksi Capital Lease. Karena memenuhi kriteria sifat transaksi Capital Lease maka ada resiko PSAK 107 dan Fatwa DSN-MUI No. 27/DSNMUI/III/2002 tidak relevan lagi untuk dipraktikkan pada akad IMBT.

Oleh karena itu, dengan hasil analisis yang dilakukan oleh peneliti terkait praktik akad IMBT setelah Fatwa DSN-MUI No. 85/2012 ternyata standar akuntansi yang menjadi pedoman pelaksanaan akad IMBT yaitu PSAK 107 perlu dikembangkan lagi karena ada risiko bahwa PSAK 107 menjadi tidak relevan lagi untuk diterapkan pada akad IMBT. Karena dengan berjalannya waktu kebutuhan masyarakat semakin beranekaragam sehingga pedoman yang dahulu masih mampu menaungi sebuah transaksi yang diaturnya ternyata kini memerlukan pengembangan seperti yang terjadi pada PSAK 107. Pihak pemerintah yang terkait perlu melakukan kajian terhadap hasil penelitian yang dilakukan oleh akademisi sehingga hasil temuan yang didapatkan bisa memberikan kontribusi terhadap kebijakan yang dikeluarkan oleh pemerintah.

\section{SIMPULAN DAN SARAN Simpulan}

Fatwa DSN-MUI No. 85/2012 memiliki beberapa dampak khususnya pada akad yang menggunakan $W a^{\prime} d$, diantaranya: 1) Fatwa DSN-MUI No. 85/2012 memberikan peluang kepastian hukum dan jaminan keberlangsungan transaksi. 2) Fatwa DSNMUI No. 85/2012 secara substansial menimbulkan potensi ketidakpatuhan syariah pada akad IMBT sebagai akibat tidak dapat diterapkan secara keseluruhan isi dari Fatwa DSN-MUI No. 27/DSN-MUI/III/2002. 3) Pedoman akuntansi yang sekarang berlaku untuk akad IMBT yaitu PSAK 107 berisiko tidak relevan lagi untuk diterapkan pada akad IMBT. Hal ini dikarenakan dengan berlakunya Fatwa DSN-MUI No. 85/2012 berakibat adanya risiko akad IMBT memenuhi kriteria transaksi Capital Lease pada proses perpindahan obyek sewanya.

\section{Saran}

Keterbatasan dalam penelitian ini adalah pada saat penelitian ini dilaksanakan, draft PSAK khusus tentang $W a^{\prime} d$ sedang disusun sehingga belum dapat dipastikan bagaimana penerapan akuntansi $W a^{\prime} d$ dan kaitannya dengan PSAK 107. Bagi penelitian selanjutnya perlu dilakukan komparasi implikasi $W a^{\prime} d$ terhadap PSAK 107 dan akad lain nya yang mengandung akad $W a^{\prime} d$. Implikasi dari hasil penelitian ini setidaknya memberikan gambaran akademis mengenai potensi risiko ketidakpatuhan syariah terhadap penerapan akad $W a^{\prime} d$ mengikat. Selain itu, menjadi bahan pertimbangan bagi dewan standar akuntansi syariah dalam hal mengkaji implikasi Fatwa DSN-MUI No. 85/2012 terhadap relevansi PSAK 107.

\section{DAFTAR PUSTAKA}

Abdullah, N. I. 2010. Status and implications of promise (wa'd) in contemporary Islamic banking. Humanomics 26(2): 8498. https://doi.org/10.1108/08288661 011074891

Alamsyah, H. 2015. Perkembangan dan Prospek Perbankan Syariah Indonesia: Tantangan Dalam Menyongsong MEA 2015. Diambil dari www.bi.go.id. Diakses pada 31 November 2015.

Al-Imrani, A. 2006. Al-Uqud al-Maliyah alMurakkabah. Riyadh: Dar kuniz Eshbelia.

Al-Muslih. 2004. Figh Ekonomi Keuangan Islam. Darul Haq. Jakarta.

Ariyanti, F. 2015. Kejar Pertumbuhan Ekonomi 5,2\%, BI Siap Beri Stimulus?. Diambil dari Koran Online. http:// bisnis.liputan6.com. Di akses pada 29 April 2016. 
Arwan, F. M. 2009. IMBT sebagai Hukum Perjanjian Sewa-Beli dalam Ekonomi Syariah. Jurnal Badilag. http://www. arsip.badilag.net. Diakses pada 13 Febriari 2016.

Ascarya. 2007. Akad dan Produk Syari'ah. Raja Grafindo Raya. Jakarta.

Azzam, A. A. M. 2010. Figh Muamalat Sistem Transaksi dalam Figh Islam. Jakarta: Amzah.

Bello, S. A. A., dan B. R. Hassan. 2012. The Scope and Application of Wa' Ad, Muwa'Adah and Wa'Dan in Islamic Finance. Ssrn 1(1): 1-11. https://doi. org/ 10.2139/ssrn.2178340.

Dewan Syariah Nasional MUI. 2000. Fatwa Dewan Syariah Nasional Tentang Ijarah. MUI. Jakarta.

Dewan Syariah Nasional MUI. 2002. Fatwa Dewan Syariah Nasional Tentang IMBT. MUI. Jakarta.

Dewan Syariah Nasional MUI. 2012. Fatwa Dewan Syariah Nasional Tentang $W a^{\prime} d$. MUI. Jakarta.

Djuwani, D. 2008. Pengantar Figh Muamalah. Pustaka Pelajar. Yogyakarta.

Fuadi, M.Y. 2007. Pelaksanaan Al-Ijarah AlMuntahiyah Bi Al-Tamlik Di BMT Harapan Umat Klaten. Skripsi. Yogyakarta: Program Sarjana UIN Sunan Kalijaga.

Hammad, N. 2005. Al-'Uqûd al-Murakkabah fi al-Figh al-Islâmy. Damaskus: Dâr alQalam.

Hijrianto, D. 2010. Pelaksanaan Akad Pembiayaan Ijarah Muntahiyah Bittamlik pada Bank Muamalat Indonesia Cabang Mataram. Tesis. Semarang: Program Pascasarjana Universitas Diponegoro.

DSAS. 2016. Standar Akuntansi Syariah Efektif Per 1 Januari 2017 (1st ed.; IAI, ed.). Retrieved from iaiglobal.or.id.

Karim, A. A. 2006. Bank Islam (Analisis Figh dan Keuangan). Raja Grafindo Persada. Jakarta.

Miles, B. M. dan M. Huberman. 1992. Analisis data kualitatif. UIP. Jakarta.

Mingka, A. 2013. Hibryd Contract dalam Keuangan Syariah. http://www.agustiantocentre.com.

Diakses pada 5 Januari 2016.

Nazir, H. dan M. Hasannuddin. 2004. Ensiklopedi Ekonomi dan perbankan Syariah. Kaki Langit. Bandung.

Nazir, M. 2011. Metode Penelitian. Ghalia Indonesia. Jakarta.

Noor, N. A. M. dan M. A. B. Aripin. 2010. Mechanism of Al-Wad (Promise): Theory and Application in Islamic Banking in Malaysia. Canadian Social Science 6(1): 80-90. Diakses 28 Desember 2015.

Nurhayati, S dan Wasilah. 2013. Akuntansi Syariah di Indonesia. Salemba Empat. Jakarta.

Ramli, H. 2005. Teori Dasar Akuntansi Syariah. Jakarta: Renaisan.

Sabiq, S. 1987. Fikih Sunah 13. Terjemahan Kamaluddin A. Marzuki. Al Ma'arif. Bandung.

Sjahdaini, S. R. 2005. Perbankan Islam dan Kehidupan Tata Hukum Perbankan Indonesia. Pustaka Utama Grafiti. Jakarta.

Smith, J. M. dan K. F. Skousen. 1984. Intermediate Accounting Comprehensive Volume $8^{\text {th }}$ Edition. Ohio: South Western Publising Co.

Sugiono. 2005. Metode Penelitian Administrasi. Alfabeta. Bandung.

Sutardi, T. 2009. Ijarah (Aplikasinya Pada Lembaga Keuangan Syari'ah). www. patanahgrogot.net. Diakses pada 08 Desember 2015.

Undang-Undang Republik Indonesia Nomor 21 Tahun 2008 tentang Perbankan Syariah. 2008. Jakarta.

Za'tary, A. 2008. Fiqh al-Muamalat alMaliyah al-Muqarin. Riyadh: Dar Usama.

Zaky, A. 2014. Analisis Alternatif Pembiayaan Take Over Berdasarkan Prinsip Syariah (Hawalah). 01(02): 113-124. Retrieved from http://imanensi.fordebi.or.id/ index.php/imanensi/article/view/12/ 12.

Zeid, M. 2004. Metode Penelitian Kepustakaan. Yayasan Obor Indonesia. Jakarta. 